\title{
INDEMNITY AND INSURANCE CLAUSES IN JOINT VENTURE, FARMOUT AND JOINT OPERATING AGREEMENTS*
}

\begin{abstract}
Many oil and gas operations conducted under a joint venture agreement are accompanied by liabilities for losses and damages, and parties to the joint venture look to the agreement to determine responsibility for such liabilities. The indemnity clause is a common contractual method of allocating liability. In addition to a contractual indemnification, the party being indemnified takes a covenant from the indemnitor that he will obtain insurance against the risk of liability. This article discusses the use of indemnity and insurance clauses in joint venture agreements and analyzes the problems which are most often encountered in the drafting of indemnity and insurance clauses in joint venture agreements.
\end{abstract}

\section{A. GENERAL CONSIDERATIONS}

Rarely does a farmout agreement, a joint venture agreement or a joint operating agreement fail to have a clause requiring one party to indemnify the other against loss suffered in particular instances. Some questions arise both as to the need for such clauses and the limitations of such clauses.

Halsbury defines a contract of indemnity as "a contract whereby one party agrees to save the other harmless from loss." Thus, in this broad sense, a contract of indemnity includes insurance contracts and guarantees. This paper, however, will be concerned, firstly, with contracts wherein one party agrees to save the promisee harmless against the claims of third parties, and secondly, to save the promisee harmless against the loss of his own property. We will not be concerned with an undertaking to answer for the default of a third person in the performance of an obligation to the promisee.

The right to indemnification may arise from contract, from circumtances or from statute. Lord Wrenbury said as follows:"

A right to indemnity generally arises from contract express or implied, but it is not confined to cases of contract. A right to indemnity exists where the relation between the parties is such that either in law or in equity there is an obligation upon the one party to indemnify the other. There are, for instance, cases in which the state of circumstances is such that the law attaches a legal or equitable duty to indemnify arising from an assumed promise by a person to do that which, under the circumstances, he ought to do.

Commenting on the common law right to indemnification by reason of circumstance, Halsbury states as follows: ${ }^{3}$

When an act is done by one person at the request of another [or for his benefit], and the act is not in itself manifestly tortious to the knowledge of the person doing it, and it turns out to be injurious to the rights of a third party, the person doing it is entitled to an indemnity from him who requested that it should be done. ... The principle does not apply where the injury to the third party arose not as the natural and necessary consequence of the doing of an act but merely from the manner in which the act was done.

- This paper was prepared by D. O. SABEY, Barrister and Solicitor, Saucier, Jones, Peacock, Black, Gain, Stratton and Laycraft, Calgary, Alberta, and by J. L. FINGARSON. Bell and Code, Calgary, Alberta.

118 Halbury's Laws 528, (3d ed).

2 Eastern Shipping Co. v. Quah Beng Kee (1924) A.C. 177 at 182. See also Best, C.J.; in Adanson v. Jarvis (1827) 4 Bing. 66; Middleton. J.A. in Proctor v. Seagram (1925) 56 O.L.R. 632 at 634 : McEwen v. Armour (1928) 2 D.L.R. 958 at 960 , and Trans-Canada Forest v. Heaps (1952) 3 D.L.R. 637 .

3 Halsbury's, supra n. 1 , at 530 . 
In this latter event, if the liability arises from the manner in which the act is done, the actor must indemnify the other. In this regard the actual degree of control exercised over the manner of operation, as distinct from the right to control, is likely to weigh heavily with a court.

It is our view that most of the indemnification clauses contained in agreements which we have reviewed do not go beyond, but are restatements of the common law, and are, to that extent, unnecessary to the agreement, even in a Rylands v. Fletcher' situation which imposes strict liability without the presence of negligence. It is recognized however that indemnification clauses can, and do, alter the common law relationship, and may also have a direct bearing on insurance risks. We also recognize that for practical purposes it is easier for one to convince a party of his obligations if one can say, "Here it is in the contract!" than if one can only say, "My lawyer tells me this is the common law." As our present concern is not with lawsuits, but with avoiding involvement we shall proceed on the assumption that these agreements will continue to contain indemnification clauses.

\section{B. CONSTRUCTION AND INTERPRETATION}

When an indemnification clause is included in an agreement, the existence of any right to indemnification by the terms expressed in that agreement depends upon those terms as interpreted by the court. The leading case setting out the principles of construction applicable to indemnification clauses is Canada Steamship Lines Ltd. v. Regem." In that case the terms of a lease provided that the lessee would at all times indemnify the lessor against all claims and demands, loss, costs, damages, actions, suits or other proceedings occasioned by or attributable to the execution of the lease or any action taken or things done or maintained by virtue of the lease or the exercise in any manner of rights arising under the lease. The headnote summarizes the decision of the Privy Council, sitting on appeal from the Supreme Court of Canada as follows:

Held: A clause purporting to exempt a party to a contract from liability for negligence must contain express language to that effect; in the absence of such language, but if the words used were wide enough, in their ordinary meaning, to cover negligence, the existence of a possible ground of damage other than that of negligence might deprive the party of the protection of the clause on a claim for negligence; . . .

In arriving at its decision the Privy Council considered and relied on the principle stated by Lord Greene, M.R., in Alderslade v. Hendon Laundry Ltd., as follows: "

... where the head of damage in respect of which limitation of liability is sought to be imposed by such a clause is one which rests on negligence and nothing else, the clause must be construed as extending to that head of damage, because, if it were not so construed it would lack subject-matter. Where, on the one hand, the head of damage may be based on some ground other than that of negligence, the general principle is that the clause must be confined to loss occurring through the other cause to the exclusion of loss arising through negligence. The reason for that is that if a contracting party wishes in such a case to limit his liability in respect of negligence, he must do so in clear terms, and in the absence of such clear terms the clause is to be construed as relating to a different kind of liability and not to liability based on negligence.

4 (1868) L.R. 3 H.L. 330

' (1952) 1 All E.R. 305. (1952) 5 W.W.R.' (N.S.) 609. (1952) A.C. 192. See also Canadian Pacific Railway Co. v. B.C. Forest Products Ltd. (1966) 54 W.W.R. 129: Collins v. Richmond Rodeo Riding Ltd. (1966) 55 W.W.R. 289 and Beauchamp v. Consolidated Paper Corp. (1961) 29 D.L.R. (2d) 254.

(i) (1945) 1 All E.R. 244 at 245, (1945) K.B. 189. 
It is worthy of note that although the two cases deal with completely different types of clauses, that is exemption clauses and indemnity clauses, the reasoning relied on is essentially the same.

The court, in construing these clauses, will be strict. Therefore if the party seeking indemnity does not fall squarely within the terms of the agreement he may have no relief, and may find that he has denied himself the desired relief because of incautious or vague general draftsmanship. One large, but unnamed, organization in Canada has nicely avoided the problem of the courts construing against the author, by ending its indemnification clause with the words ". . . everything except negligence on the part of the farmor.":

Recognizing a need for such clauses in the industry, it is nonetheless felt that the agreements should recognize the change of status or relationship of the parties during the course of performance under the agreement. For example, in most farmout agreements the relationship with a farmee changes once he has earned his interest. It is the commonly, and properly, accepted view that during the period of earning his interest the farmee should bear the risks and should indemnify the farmor for losses incurred by the manner in which he conducts his operations. However, once the interest is earned the right of indemnification should properly be limited by applying the principles applicable in a partnership where: ${ }^{*}$

Each member as an agent of the firm is entitled to be indemnified by the firm against losses and expenses bona fide incurred by him for the benefit of the firm, whilst pursuing the authority conferred upon him by the agreement entered into between himself and his co-partners. On the other hand, a partner has no right to charge the firm with losses or expenses incurred by his own negligence or want of skill, or in disregard of the authority reposed in him.

If the relationship between the parties is akin to one of partnership, then it is questionable whether any indemnity provision should be inserted or made applicable. For example, if liability in a situation arises completely without fault, should not the loss be apportioned rather than shifted entirely to the operator?

We should point out that while the same agreement usually imposes an obligation to insure, the premiums for which are operating expenses, the covenant to insure is not a complete answer as there are risks beyond those covered by insurance. In these instances the parties should decide if one is to indemnify the other or if apportionment or contribution should be applied.

\section{INSURANCE ASPECTS}

In drafting clauses setting out insurance requirements, nót only must the usual indemnity provisions be considered, but also the types of insurance available. A standard insurance clause is as follows:

Farmee shall, throughout the terms of this Agreement, comply with and require its contractors to comply with the applicable Workmen's Compensation laws and in addition, and without in any way limiting the liability of the Farmee under this Agreement, it shall be the responsibility of Farmee to obtain and keep in force during the terms of this Agreement, the following insurance:

(i) Automobile Liability Insurance-covering all vehicles used in connection with operations under this Agreement. In respect of such vehicles not owned by the Farmee, it shall maintain and keep in force as aforesaid, non-owned

i See Sedmon v. Moore (1946) O.W.N. 510.

$\checkmark$ Lindley on Partnership 398 (12th ed.). 
automobile liability insurance protecting its liability including that assumed under this contract. The limits of insurance under this provision shall be not less than:

Bodily Injury (including Passenger Hazard) and Property Damage: $\$ 500,000$ inclusive any one accident or equivalent limits.

(ii) Comprehensive General Liability Insurance-covering all operations in connection with this Agreement (other than the operation of automobiles), including employer's liability, the Farmee's contingent liability with respect to the operation of subcontractors, and contractual liability as respects the liability assumed by the Farmee under this Agreement. The foregoing policy or policies shall include dąmage resulting from fire, explosion, or blowouts (excluding subsurface damage). The limits of such insurance shall not be less than:

Bodily Injury and Property Damage: $\$ 500,000$ inclusive any one accident, or equivalent limits.

The property damage insurance may be purchased with a deductible, but the amount of any deductible must be agreed to by the other parties to the Agreement;

and shall upon request deliver to Farmor evidence of such insurance.

To this clause could be added a provision for direct loss insurance where an operator is responsible for property owned by all of the parties to the agreement.

With respect to automobile insurance, it is in a standard form and we do not propose to make any comment in this regard. With respect to direct loss insurance on property owned by the various parties to the agreement, this can be obtained under an all risk form of contract or a contract limited to specified perils. Various insurance brokers are well qualified to comment on the types of direct loss insurance.

Turning to comprehensive general liability coverage, we have found that the forms in use are not standardized and consequently the form and content of each individual policy should be considered prior to purchase. Liability policies do not necessarily include a right of indemnity with respect to "liability assumed under contract". The courts" have drawn a distinction between the phrases "imposed by law" and "assumed under contract", and consequently the policy should cover liability "assumed under contract", for the cases make it clear that a contract voluntarily entered into carries with it liabilities which will be construed as "assumed under contract". Insurers are reluctant to extend coverage to include contractual liability unless specifically requested to do so, and some policies require the filing of contracts with the insurer before coverage will be afforded.

The terms of coverage and the exclusions in the liability policies must be considered. The following insuring agreements are found in some policies in use in this area, and the examples chosen afford broad coverage in comparison to many other policies in use:

The insurer will pay on behalf of the insured subject to the following terms, conditions and exclusions, all sums which the insured shall become obligated to pay by reason of the liability:

(a) Imposed upon them by law or assumed under any written agreement or written contract for loss or damage (including damages for care and loss of services) because of bodily injury, sickness, illness, disease or mental anguish including death at any time resulting therefrom, sustained by any person or persons occurring during the document period and arising out of and incidental to the operations of the Insured:

(b) Imposed upon them by law or assumed by them under written agreement or written contract because of damage to or destruction of property, includ-

9 Dominion Bridge v. Toronto General Insurance Company (1962) 37 W.W.R. 673. See also Canadian indemnity Company v. Andrews \& George (1953) 1 S.C.R. 19. 
ing loss of use thereof, occurring during the document period and arising out of and incidental to the operations of the Insured:

Another type of comprehensive contract reads as follows:

To pay on behalf of the insured, all sums which the insured shall become obligated to pay by reason of the liability imposed upon him by law, or assumed by him under 'insured contract' as defined below . . .

Insured contract is defined as:

. . . a specific agreement made as part of a contract to perform work or supply material for or to another, to indemnify that other in respect of liability imposed by law upon that other because of bodily injury or injury to or destruction of property arising out of the said work being performed or the material being supplied; or any other written agreement of which a copy has been presented to and accepted by the insurer prior to the date of occurrence or accident covered by the terms of this section.

It will be noted that liability assumed under contract is covered in both policies, and that in the second policy there is a requirement for filing any contract in which an obligation more onerous than that imposed at common law is assumed. The distinction no doubt arises from the premium rating of the two policies and the requirement for filing allows the insurer under the second policy to assess the risk in determining the premium for the additional risk assumed.

Turning to exclusions there are some standard ones which we need only comment upon briefly. Generally there are exclusions deleting coverage with respect to risks covered by automobile and aircraft policies, and for damage or destruction to property owned, used by or in the care, custody or control of the insured. The latter risks are covered by direct loss policies.

Almost invariably underground damage will be excluded and the form of one such exclusion in use is as follows:

The insurer shall not be liable hereunder in respect of Injury to or destruction of any oil and/or gas well or hole which is being worked on by the insured. It is understood and agreed, however, that the term "well" as used herein shall not be deemed to include well head equipment or apparatus of a similar nature.

The exclusion which the industry clearly does not want to find in a policy is one reading "liability assumed by the insured under any contract or agreement".

One further matter should be considered with respect to insurance. Often insurance provisions in contracts only require the party obtaining the insurance to supply "certificates of the insurance carried" and often such certificates are not detailed enough to be of any assistance in considering the questions raised above. We are of the opinion that in addition to the requirement of certificates, there should be an obligation "to supply certified copies of such policies if requested" so that the actual wording of the insuring agreements and exclusions can be considered.

In all policies of insurance the names of the persons insured should be considered and this is usually included in the definition of the word "insured". All parties involved in the operation should be covered and further in some cases the company may wish coverage to be extended to officers and employees. Generally speaking employees are not covered in such policies. This situation has arisen because the Workmen's Compensation Board in the Province of Alberta has adopted a policy of attempting to collect rather substantial sums from insurers which 
sums would at law not be recoverable from the employer by reason of the provisions of The Workmens Compensation Act. The net effect of the situation is that the employers are bearing the cost of such losses in two manners; by premiums on their policies and by contribution by way of assessments under The Workmen's Compensation Act.

In summary, we have sought to point out that indemnification and insurance clauses are related, that they should be considered together to see that the result of both clauses is to shift the risk on an equitable basis, and that the proper type of insurance coverage is obtained, having regard to the risk being shifted. In that regard it should be kept in mind that some risks are uninsurable, and some risks arise without fault, and further that what may be reasonable in a farmout agreement may not effect the intended result when inserted in another situation where joint obligations arise. Generally, the clauses should be read together and considered to ascertain that the true intention of the parties is being satisfied. Policies of insurance should be carefully considered in light of obligations assumed by indemnification clauses. 